\title{
norden
}

\section{Clearing og oppgjør i Norden}

- særlig om forholdet til Giovannini-rapporten av november 2001

Rapport utarbeidet i regi av Nordisk Ministerråd

TemaNord 2004:535 
Clearing og oppgjor i Norden

- særlig om forholdet til Giovannini-rapporten av november 2001

TemaNord 2004:535

(C) Nordisk Ministerråd, København 2004

ISBN 92-893-1029-4

ISSN 0908-6692

\author{
Nordisk Ministerråd \\ Store Strandstræde 18 \\ DK-1255 København K \\ Telefon $(+45) 33960200$ \\ Telefax (+45) 33960202
}

\author{
Nordisk Råd \\ Store Strandstræde 18 \\ DK-1255 København K \\ Telefon (+45) 33960400 \\ Telefax $(+45) 33111870$
}

www.norden.org

Det nordiska ekonomiska och finansiella samarbetet

Det nordiska ekonomiska och finansiella samarbetet omfattar nationell och internationell stabiliseringspolitik, studier och diskussioner om olika strukturpolitiska ämnen samt Nordens anpassning till den ekonomiska integrationen i Europa. Arbetet leds av ekonomi- och finansministrarna, och Ämbetsmannakommittén för ekonomi- och finanspolitik fungerar som förberedande organ.

\section{Nordisk Ministerråd}

blev oprettet i 1971 som samarbejdsorgan mellem de nordiske landes regeringer. Ministerrådet fremlægger forslag til Nordisk Råds sessioner, viderefører rådets rekommandationer, rapporterer til Nordisk Råd om samarbejdets resultater og leder arbejdet inden for de forskellige emneområder. Samarbejdet koordineres af samarbejdsministrene, der er udpeget af det enkelte lands regering. Ministerrådet træder sammen i forskellige sammensætninger - afhængigt af hvilke spørgsmål, der skal behandles.

\section{Nordisk Råd}

blev oprettet i 1952 som et samarbejdsorgan mellem de folkevalgte forsamlinger og regeringer i Danmark, Island, Norge og Sverige. Finland indtrådte i 1955. Færøernes, Grønlands og Ålands delegationer indgår i henholdsvis Danmarks Riges og Finlands delegationer. Rådet består af 87 medlemmer. Nordisk Råd er initiativtagende og rådgivende og har kontrollerende opgaver i det nordiske samarbejde. Nordisk Råds organer er plenarforsamlingen, præsidiet og udvalgene. 


\section{Innhold}

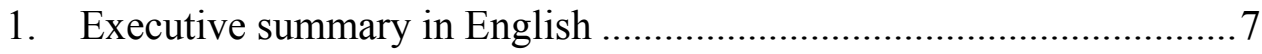

2. Innledning og sammenfatning...................................................... 9

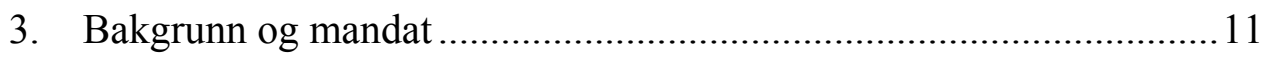

4. Oversikt over nasjonale clearing- og oppgjørssystemer ................... 13

4.1 Hva er clearing og oppgjør?..................................................... 13

4.2 Clearing- og oppgjørssystemer i de nordiske land..................... 13

5. Nærmere om Giovannini-rapporten .............................................. 15

6. De ulike barrierene i Giovannini-rapporten ..................................... 17

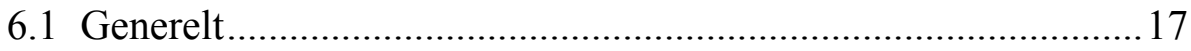

6.2 Barrierer relatert til tekniske krav/markedspraksis.................... 17

6.3 Barrierer relatert til forskjeller i nasjonale skatteregler ..............20

6.4 Barrierer relatert til rettslig sikkerhet .....................................21

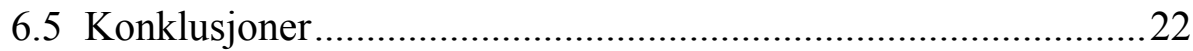




\section{Executive summary in English}

The purpose of this report is to identify potential legal barriers in the Nordic countries (i.e. Denmark, Finland, Iceland, Norway and Sweden) to effective cross border clearing and settlement as identified in the "Giovannini-report" of November 2001.

Apparently, there are few legal provisions in Nordic countries creating technical barriers as defined in barriers no. 1-10 in the Giovannini-report. As for taxation (barriers no. 11-12), some barriers are identified. However, the main barriers as regards taxation are probably of a more general nature than the barriers discussed in the Giovannini-report. Furthermore, relatively few barriers are identified in relation to legal uncertainty (barriers no 13-15). However, general uncertainty in relation to treatment of nominee accounts might be a potential impediment to effective clearing and settlement in the Nordic countries.

It should be emphasised that the relatively small number of "Giovannini-barriers" identified in this report does not necessarily imply that the Nordic market for clearing and settlement would be regarded as homogeneous and cost efficient. General differences in technical solutions and different rules on taxation and tax reporting probably amounts to potential impediments to cross border clearing and settlement between the Nordic countries. 


\section{Innledning og sammenfatning}

I november 2001 avga den sk. Giovannini-gruppen en rapport til EU-kommisjonen hvor det ble identifisert 15 ulike barrierer for effektiv clearing- og oppgjørsvirksomhet over landegrensene.

I det følgende gjennomgås blant annet de ulike "Giovannini-barrierene" med sikte på å identifisere hindringer for effektiv clearing- og oppgjør mellom de nordiske land som skyldes ulike nasjonale rettsregler.

På samme måte som i Giovannini-rapporten gjennomgås tre ulike grupper av barrierer, knyttet til hhv tekniske forhold, skattemessige forhold og rettslig usikkerhet. Konklusjonene for de ulike gruppene er som følger:

- Det foreligger enkelte tekniske hindringer (barriere nr. 1-10), men dette er forhold som generelt bør reguleres av markedsutviklingen og markedsaktørene. Myndighetene bør være tilbakeholdne med å påtvinge aktørene bestemte tekniske løsninger. Samtidig bør myndighetene være forsiktige med å gi lovregler som i praksis påtvinger særskilte tekniske løsninger som kan vanskeliggjøre effektiv clearing og oppgjør mellom nordiske land. Det er ikke identifisert særskilte lovregler som forhindrer en hensiktsmessig teknisk utvikling på dette området.

- Det foreligger relativt få skattemessige hindre av den type som særskilt nevnes i Giovannini-rapporten (barriere nr. 11 og 12). Det synes imidlertid som om Danmark har et etableringskrav knyttet til administrasjon av tilbakeholdsskatt som etter omstendighetene kan utgjøre en barriere som nevnt i Giovannini-rapporten (barriere nr. 11). For øvrig kan det legges til grunn at ulike skatteregler mellom nordiske land og ulikheter mht skatteadministrasjon i seg selv kan utgjøre en barriere for effektiv clearing og oppgjør over landegrensene, men dette er forhold som faller utenfor denne fremstillingen.

- Når det gjelder rettslig usikkerhet (barriere nr. 13-15), er det generelt stor grad av samsvar mellom de nordiske lands mer grunnleggende regulering av eiendomsrett og rettigheter til verdipapirer. De ulikheter i nasjonal lovgivning som diskuteres i Giovannini-rapporten, vil uansett reduseres som følge av gjennomføringen av collateral-direktivet og Haag-konvensjonen i nasjonal rett. Det kan imidlertid oppstå rettslig usikkerhet ved forvalterregistrering. I de fleste nordiske land kan det oppstå vanskelige tolkingsspørsmål i denne sammenheng. I Norge kan det for eksempel oppstå usikkerhet om rettsvern til forvalterregistrerte instrumenter, siden det ikke er gitt lovregler som regulerer deres prioritet i forhold til andre investorer (registrert hos samme forvalter) eller forvalters konkursbo.

- Det understrekes at relativt få "Giovannini-barrierer" av rettslig karakter, ikke nødvendigvis innebærer at det er et kostnadseffektivt system for grensekryssende clearing og oppgjør i Norden. Det lave antallet fjernmedlemmer i de ulike nordiske clearing- og oppgjørssystemer (i forhold til antallet fjernmedlemmer på børsene) og det relativt lave antallet direkte lenker mellom nordiske systemer (en slik lenke finnes i dag bare mellom svenske VPC og finske APK og mellom 
danske VP og VPC) tyder tvert i mot på at det faktisk foreligger hindre (dog av en annen art) på dette området. Slike andre hindre (dvs hindre som ikke nevnes i Giovannini-rapporten) faller utenfor denne fremstillingen, men en kan trolig legge til grunn at tekniske løsninger og ulike skatteregler er viktige grunner til den relativt lave grensekryssende aktiviteten på dette området. Skatt omtales noe nærmere under punkt 6.3.

I det følgende vil det under punkt 4 gis en oversikt over de nasjonale systemer for clearing og oppgjør (herunder hva som menes med clearing og oppgjør), mens Giovanninirapporten vil omtales nærmere under punkt 5. I punkt 6 foretas en konkret gjennomgang av de 15 barrierene som identifiseres i Giovannini-rapporten. Først gis imidlertid en gjennomgang av den faktiske bakgrunn og mandatet som ligger til grunn for denne rapporten. 


\section{Bakgrunn og mandat}

I 1999 ga Nordisk Ministerråd ut rapporten "Förutsettningar för ökat nordiskt och nordiskt-balktiskt börssamarbete". Som en del av oppfølgingen til denne rapporten ble det nedsatt en arbeidsgruppe som våren 2000 avga rapporten "Registrering, Clearing og afvikling på det Nordiske værdipapirmarked nu og i fremtiden - og eventuelle hindringer herfor". Denne rapporten konkluderte bl.a. med at det var behov for en nærmere gjennomgang av de nordiske lands regler om registrering og rettsvirkninger av registrering. På denne bakgrunn ble det nedsatt en arbeidsgruppe som høsten 2001 avga rapporten "Registrering af værdipapirer i de nordiske lande". Denne rapporten understreket bl.a. viktigheten av at:

"...reglerne skal være fleksible, idet de bør muliggøre etableringen af effektive og sikre clearing- og afviklingssystemer samt tage hensyn til andre landes systemer for afvikling af forpligtelser. Dette er af særlig betydning for afviklingen af den handel, som sker på markedspladserne og mellem professionelle aktører på markedet. Endvidere skal den enkelte investors krav på beskyttelse honoreres. Der vurderes således at være baggrund for en fælles ændring på dette område. (s. 9-10)".

På denne bakgrunn ba ÄK-Finans Norge om å lede arbeidet med å "utreda behovet av och ev. föreslå nödvändiga ändringar av rättsverkningar vid registrering i förhållande till samverkan mellan reglerna för avveckling og clearing”. Videre ble det besluttet på møte i referansegruppen 5. april 2002 at en slik vurdering også skulle omfatte en vurdering av de rekommandasjoner som oppstilles i Giovannini-rapporten. På denne bakgrunn forberedte Norge et utkast til rapport som ble sendt til samtlige land sommeren 2002, med frist for tilbakemelding september 2002. Det viste seg imidlertid å være noe vanskelig å få merknader fra alle land innen fristen. På møte i referansegruppen 4. mars 2003 ble det besluttet å endre gruppens mandat, slik at gruppen kun skal ferdigstille en oversikt over de nordiske lands forhold til de ulike barrierer som er identifisert i Giovannini-rapporten.

Et viktig virkemiddel i denne sammenheng har vært et spørreskjema hvor samtlige land har gitt kommentarer til de enkelte barrierer identifisert i Giovannini-rapporten. Siste innspill i denne prosessen ble mottatt sommeren 2003. Et utkast til foreliggende rapport har blitt utarbeidet i det norske finansdepartementet, og den har blitt ferdigstilt etter innspill pr. e-post fra de andre nordiske land. Det har ikke vært ansett å være nødvendig med et eget møte i saken. 


\section{Oversikt over nasjonale clearing- og oppgjørssystemer}

\subsection{Hva er clearing og oppgjør?}

Begrepsbruken vedrørende de prosesser som skjer i etterkant av handel (post-trade) er ikke homogen. I denne rapporten forstås med "clearing" den operasjon hvor kjøpers og selgers leveringsforpliktelser av hhv penger og papirer utregnes, dvs. bringes på det rene. "Oppgjør" omfatter den operasjon hvor verdipapirene leveres, og betalingen for papirene finner sted. Disse operasjonene gjennomføres i ulike institusjoner i de nordiske landene.

I det følgende omtales kun clearing og oppgjør av verdipapirer (dvs. ikke derivater mv.).

\subsection{Clearing-og oppgjørssystemer i de nordiske land}

I Norge foretas clearingen av Verdipapirsentralen (VPS) som er det nasjonale rettighetsregisteret (CSD). På oppgjørssiden skjer levering av verdipapirer i VPS, mens pengeoppgjøret skjer i Norges Bank.

I Sverige foretas clearingen i VPC som er det nasjonale rettighetsregisteret. Levering av verdipapirer skjer også i VPC, mens pengeoppgjøret skjer i Sveriges riksbank.

I Danmark foretas clearingen i Værdipapircentralen AS (VP) som er det nasjonale rettighetsregisteret. Levering av verdipapirer skjer også i VP, mens pengeoppgjøret skjer i Danmarks Nationalbank.

I Finland foretas clearingen i APK som er det nasjonale rettighetsregisteret. Levering av verdipapirer skjer også i APK, mens pengeoppgjøret skjer i Finlands Bank.

I Island foretas clearingen i ISD som er det nasjonale rettighetsregisteret. Levering av verdipapirer skjer også i ISD, mens pengeoppgjøret skjer i Sedlabanki Islands.

Det er viktige fellestrekk ved de nordiske rettighetsregistrene, som skiller dem fra vesentlige punkter fra en del andre europeiske rettighetssystemer. Dette gjelder særlig at det foretas registreringer på både investornivå og mellommannsnivå (og ikke bare på mellommannsnivå). Dette er nærmere omtalt $i$ "Registrering af værdipapirer i de nordiske lande" av september 2001 (rapport fra en arbeidsgruppe under Nordisk Ministerråd). 


\section{Nærmere om Giovannini-rapporten}

Giovannini-rapporten ${ }^{1}$ av november 2001 gjør nærmere rede for hvilke utfordringer en står overfor ved grensekryssende clearing og oppgjør. Generelt viser rapporten at det internt i det enkelte EU-land er effektive nasjonale systemer som kostnadsmessig er på linje med det en finner bl.a. i USA. Grensekryssende clearing- og oppgjør er imidlertid kostbart, og dette er til hinder for å skape et reelt indre marked for finansielle tjenester.

Den første Giovannini-rapporten går gjennom 15 ulike barrierer som antas å være til hinder for effektiv clearing- og oppgjørsvirksomhet over landegrensene (innen EØS). Som nevnt er det disse barrierene som er tema for den foreliggende rapporten.

Giovannini-gruppen utarbeidet en rapport nr. 2 til EU-kommisjonen i april 2003. Det sentrale formålet med den andre Giovannini-rapporten er å angi hvilke tiltak som er nødvendige for å fjerne de barrierene som ble identifisert i den første rapporten.

De to Giovannini-rapportene utgjør imidlertid bare en del av de ulike prosesser som pågår i Europa på dette området. I denne sammenheng nevnes særskilt Europaparlamentets rapport fra 19. februar 2003 om clearing og oppgjør, og den felles konsultative rapport fra CESR og ECB fra juli 2003. På globalt nivå nevnes særskilt rapporten fra G-30 (en privat organisasjon bestående av representanter fra næringsliv og offentlige myndigheter fra ulike land), som 23. januar 2003 publiserte en rapport med 20 anbefalinger for å skape soliditet og effektivitet i clearing- og oppgjørssystemer. Disse rapportene vil ikke omtales nærmere i denne sammenheng.

\footnotetext{
${ }^{1}$ Giovannini-gruppen er et forum som gir råd til EU-kommisjonen i enkelte finansmarkedsspørsmål.
} 


\section{De ulike barrierene i Giovannini- rapporten}

\subsection{Generelt}

Det sentrale formålet med gjennomgangen nedenfor er å gi en oversikt over eventuelle barrierer for effektive og integrerte clearing- og oppgjørssystemer mellom de nordiske land av en slik art som omtales i Giovannini-rapporten. Hovedfokus vil være på barrierer som skyldes nasjonale rettsregler, og ikke de rent tekniske forhold som markedsaktørene selv bør stå fritt til å tilpasse. Fokus vil i likhet med omtalen i Giovanninirapporten være på clearing og oppgjør av aksjer og obligasjoner.

Dette innebærer at det i det følgende ikke foretas en gjennomgang av eventuelle andre hindre (enn de som er omtalt i Giovannini-rapporten) som måtte eksistere for effektiv clearing og oppgjør mellom de nordiske land. Her skal imidlertid nevnes at ulike tekniske løsninger og ulike skatteregler (av en annen art enn Giovanni-barrierene) trolig er viktige årsaker til at det er relativt få fjernmedlemmer i de nordiske systemene, og at det er relativt få direkte lenker mellom disse systemene.

\subsection{Barrierer relatert til tekniske $\mathrm{krav} /$ markedspraksis}

Barriere nr. 1:

\section{Nasjonale ulikheter knyttet til informasjonsteknologi og grensesnitt}

I Giovannini-rapporten understrekes at effektiv kommunikasjon mellom de ulike nasjonale systemer er en forutsetning for kostnadseffektiv clearing- og oppgjør over landegrensene. Effektiv kommunikasjon forutsetter i praksis at de ulike nasjonale systemer er basert på kompatible teknologiske løsninger og grensesnitt. I motsatt fall er internasjonale investorer og verdipapirforetak henvist til å benytte lokale tilbydere av clearing- og oppgjørstjenester, gjerne med ytterligere mellommenn som kjenner de lokale forhold i landet hvor oppgjøret skal skje. Dette vil innebære ekstra utgifter sammenlignet med en rent nasjonal transaksjon, blant annet fordi flere mellomledd må benyttes og fordi konkurransen mellom tjenestetilbyderne svekkes. ECSDA (European Central Securities Depositaries Association) har utarbeidet harmoniserte kommunikasjonsformer mellom nasjonale oppgjørssystemer, bl.a. med sikte på å redusere slike kostnader.

Det fremgår av spørreskjemaet at samtlige nordiske CSD' er har standarder for grensesnitt mv. som er basert på disse anbefalingene (dvs ISO 15022 og SWIFT).

Barriere nr. 2:

Nasjonale restriksjoner mht valg av clearing og oppgjørssystemer

I Giovannini-rapporten vises til at det i enkelte land er lovregler som krever at investorer benytter det nasjonale clearing- og oppgjørssystem, f.eks. ved å kreve at handler 
inngått på den nasjonale børsen skal gjøres opp i de nasjonale oppgjørssystemer. Dette skaper særlige problemer dersom det samme instrumentet handles på flere børser. Dersom investorer kjøper og selger det samme instrumentet på ulike børser, vil et lovkrav som krever bruk av det nasjonale clearing- og oppgjørssystem innebære at investorene må forholde seg til en rekke forskjellige systemer, noe som vil øke kostnadene ved slik handel betydelig (bl.a. på grunn av krav til marginsikkerhet).

Ingen nordiske land har lovregler som begrenser valget av clearing- og oppgjørssystemer for verdipapirer. I praksis synes dette å være regulert av avtaler mellom den nasjonale børsen og de ulike clearing- og oppgjørssystemer.

\section{Barriere nr. 3}

\section{Ulike nasjonale regler mht "corporate actions" og forvalterregistrering}

I Giovannini-rapporten antas at ulik behandling av "corporate actions" i ulike land kan utgjøre en hindring for effektive clearing- og oppgjørssystemer over landegrensene. Håndteringen av "Corporate actions" i de nordiske rettighetssystemene er for øvrig nærmere omtalt i "Registrering af værdipapirer i de nordiske lande" av september 2001 (rapport fra en arbeidsgruppe under Nordisk Ministerråd). Det antas mer spesifikt at gjennomføring av standarden ISO 15022 vil avhjelpe problemer knyttet til "corporate actions". Det fremgår av svarene i spørreskjemaet at alle nordiske systemer har gjennomført eller er i ferd med å gjennomføre ISO 15022.

I Giovannini-rapporten angis også ulike nasjonale regler om forvalterregistrering som et hinder for effektive clearing- og oppgjørssystemer over landegrensene, uten at dette utdypes nærmere. Det er noe ulike regler mellom de nordiske land mht adgangen til forvalterregistrering. Dette er nærmere vurdert $\mathrm{i}$ "Registrering af værdipapirer i de nordiske lande" av september 2001 (rapport fra en arbeidsgruppe under Nordisk Ministerråd). Forholdet til forvalterregistrering drøftes derfor ikke nærmere her.

\section{Barriere nr. 4:}

\section{Fravaer av intradag oppgjør (med endelig virkning)}

I Giovannini-rapporten vises til at fravær av intradag oppgjør øker kostnadene ved grensekryssende clearing- og oppgjør (bl.a. fordi det må skaffes pant for mer enn én dag). Intradag oppgjør reduserer også systemrisikoen.

Med unntak av Island, har alle nordiske systemer mulighet for intradag oppgjør med endelig virkning. Det er ikke opplyst om lovregler som er til hinder for en hensiktsmessig markedsutvikling på dette området.

\section{Barriere nr. 5:}

Praktiske problemer mht fjernmedlemsskap i nasjonale clearing- og oppgjørssystemer

I Giovannini-rapporten vises til at det kan foreligge praktiske problemer for medlemmer i de nasjonale clearing- og oppgjørssystemer som ikke er etablert i landet (fjernmedlemmer), f.eks at bare nasjonale banker gis konto i nasjonalbanken (for pengesiden av oppgjøret).

Det foreligger ingen lovmessige hindre i de nordiske land for grenseoverskridende deltakelse i nasjonale clearing- og oppgjørssystemer. Det skal imidlertid bemerkes i denne 
sammenheng at den rettslige adgangen til fjernmedlemskap i relativt liten grad benyttes i praksis, jf. omtale under punkt 6.1.

Barriere nr. 6:

Ulike nasjonale oppgjørsperioder

I Giovannini-rapporten vises til at grensekryssende clearing- og oppgjør kompliseres ved ulike nasjonale oppgjørsperioder som fraviker fra internasjonale standarder (som er $\mathrm{T}+3)$.

Med unntak av Island, opererer alle nordiske clearing- og oppgjørssystemer med en standard oppgjørsperiode som er $\mathrm{T}+3$. Disse systemene kan imidlertid også levere $\mathrm{T}+0$ eller andre oppgjørssykluser. Det er ikke opplyst om lovregler som er til hinder for en hensiktsmessig markedsutvikling på dette området.

\section{Barriere nr. 7:}

Nasjonale forskjeller i åpningstider og oppgjørsfrister

I Giovannini-rapporten vises til at ulike åpningstider og oppgjørsfrister i nasjonale systemer medfører økte kostnader for aktørene, bl.a. fordi en ikke kan være sikker på å få levert et verdipapir i tide til å oppfylle egne forpliktelser.

Det er ulike åpningstider og oppgjørsfrister i de nordiske systemene. De systemer som har tilgang til TARGET vil etter omstendighetene ha et incentiv til å tilpasse seg TARGETs åpningstider. Det synes imidlertid ikke å foreligge lovregler på finansmarkedsområdet som er til hinder for en hensiktsmessig markedsutvikling på dette området.

Barriere $n r .8$ :

Nasjonale forskjeller mht utstedelse av verdipapirer

I Giovannini-rapporten vises til at det kan oppstå problemer med å utstede verdipapirer gjennom ulike systemer på samme dag, fordi systemene ikke har samme kapasitet til å allokere ISIN-koder mv.

Ingen særskilte regelverkshindringer er identifisert i de nordiske landene på dette området.

Barriere nr. 9:

Nasjonale restriksjoner på lokalisering av verdipapirer

I Giovannini-rapporten vises til at det i enkelte land er regler som krever at handler i noterte aksjer skal gjøres opp i det nasjonale oppgjørssystemet. Videre vises til at det i enkelte land er lovkrav om at noterte verdipapirer skal registreres i det nasjonale registeret. Det vises til at slike lovkrav kan virke hindrende på valg av clearing- og oppgjørssystem.

Enkelte nordiske land har lovregler om at verdipapirer skal "primærutstedes"2 i et register med konsesjon fra hjemlandets myndigheter. Dette er bl.a. tilfellet i Norge. I Finland

\footnotetext{
${ }^{2}$ Med "primærutstedelse" menes den operasjon som skaper verdipapirene i deres dematerialiserte form.
} 
gjelder en tilsvarende regel for børsnoterte aksjer, men tilsynsmyndighetene kan gjøre unntak. I disse landene synes det imidlertid ikke å være krav til at "nasjonale" verdipapirer må børsnoteres på den nasjonale børsen, eller at levering av papirene skal skje gjennom det nasjonale clearing- og oppgjørssystemene, jf. også ovenfor om barriere nr. 2. Krav om "primærutstedelse" i et nasjonalt register synes derfor ikke å utgjøre et slikt hinder som omtalt i Giovannini-rapporten.

\section{Barriere $n$ r. 10:}

Nasjonale restriksjoner på aktiviteten til primorhandlere og market makere

I Giovannini-rapporten vises til at det i enkelte land kreves at primærhandlere og market makere må etablere seg lokalt for å delta i nasjonale clearing- og oppgjørssystemer.

Ingen nordiske land synes å ha særskilte restriksjoner på slik virksomhet.

\subsection{Barrierer relatert til forskjeller i nasjonale skatteregler}

I Giovannini-rapporten understrekes at ulike beskatningsregler for verdipapirer generelt utgjør et hinder for grensekryssende handel i EU/EØS. De tre barrierene som omtales i rapporten er imidlertid knyttet til særskilte beskatningsproblemer knyttet til grensekryssende clearing- og oppgjør. Generelt bemerkes at det innen Norden trolig finnes en rekke skatterelaterte "hindre" for effektiv grensekryssende handel, clearing og oppgjør. Ulikheter i skattesystemene kan i seg selv utgjøre et hinder, siden ulike regler og dokumentasjonskrav innebærer at det må rapporteres ulike opplysninger til de ulike lands skattemyndigheter. Dette er imidlertid hindringer som ikke drøftes særskilt i Giovannini-rapporten, og vil derfor ikke berøres nærmere i denne sammenheng.

Barriere $n r .11$ :

Lokal tilbakeholdsskatt ("withholding tax") som virker til ulempe for utenlandske meglere

I Giovannini-rapporten vises til at det i enkelte land som krever tilbakeholdskatt ("withholding tax") diskriminerer mellom meglere som er etablert i landet og andre meglere, slik at det bare er etablerte meglerne som kan utføre oppgaver i tilknytning til innkreving og administrasjon av slik skatt.

Med unntak av Danmark, forskjellesbehandles ikke nasjonale og utenlandske forvaltere mht administrasjon av tilbakeholdskatt i de nordiske land. I Danmark holdes i utgangspunktet 28 pst tilbake, men investor kan omfattes av lavere satser dersom vedkommende er registrert i VP gjennom et dansk foretak.

Fravær av diskriminering betyr imidlertid ikke at det ikke finnes restriksjoner på området. Ulike regler og dokumentasjonskrav kan i seg selv utgjøre et hinder for grensekryssende virksomhet. Et eksempel gjelder svenske skatteregler som pålegger aktørene rent nasjonale løsninger (dette gjelder særlig kupongskatten). En aktør som har tilpasset sitt system til for eksempel svenske skatteregler og det tekniske grensesnitt som svenske skattemyndigheter krever for innrapportering av skyldig skatt, kan ikke anvende samme løsninger og grensesnitt i forhold til danske skattemyndigheter.

Barriere nr. 12: 
Omsetningsavgift som innkreves gjennom det lokale oppgjørssystem

I Giovannini-rapporten vises til at det i enkelte land kreves en omsetningsavgift ved verdipapirhandel som forutsetter deltakelse i det lokale oppgjørssystemet.

Det er ingen nordiske land som krever omsetningsavgift ved verdipapirhandel.

\subsection{Barrierer relatert til rettslig sikkerhet}

I Giovannini-rapporten gjøres nærmere rede for hva som menes med barrierer knyttet til rettslig sikkerhet. Det vises til at slike barrierer kan utgjøre en integrert del av det juridiske system i det enkelte land, og at de ikke enkelt lar seg fjerne. Dette gjelder bl.a. regler om eiendomsrett til verdipapirer mv.

\section{Barriere nr. 13:}

\section{Fravar av felles EU-regler for behandling av rettigheter $i$ verdipapirer}

I Giovannini-rapporten påpekes at EU-land har ulike nasjonale regler mht hvor et verdipapir er lokalisert, og ulike regler mht hvorledes begrensede rettigheter i verdipapirer (som pant) kan etableres og håndheves. Det vises til at initiativ knyttet til felles regler om grensekryssende sikkerhetsstillelse (collateral-direktivet som nå er vedtatt) vil bedre situasjonen, men at direktivet er begrenset til regulering av nærmere angitte sikkerhetstransaksjoner og at det ikke gir beskyttelse mot illojale transaksjoner.

Generelt bemerkes at rettssystemene i de nordiske land i stor grad er basert på sammenlignbare konsepter om eiendomsrett mv., og det er en stor grad av harmoni mellom de ulike lands tingsrett og konkurs- og panterett. De mer overordnede problemer knyttet til rettslig usikkerhet må derfor antas å være mindre ved verdipapirhandel mellom nordiske land enn mellom land som har en mindre grad av rettsenhet på disse områdene. For øvrig vil en rekke av de problemstillinger som reises i Giovannini-rapporten løses ved gjennomføringen av collateral direktivet i de nordiske land (i hvertfall innen direktivets virkeområde).

På den annen side må det antas at det også innen Norden eksisterer barrierer av denne art. Dette gjelder særlig i forhold til forvalterregistrering. I de fleste land vil det trolig oppstå vanskelige tolkingsspørsmål ved forvalterregistrering i flere ledd (f.eks i forhold til skattemyndighetenes og andre kontrollmyndigheters tilgang til opplysninger om eier), og om man ved forvalterregistrering kan legge til grunn at en "eier" det aktuelle verdipapiret, eller om en bare har et krav mot forvalter. Denne rettslige usikkerhet kan illustreres ved reguleringen av forvalterregistrering etter norsk rett. I Norge kan forvalterregistrering av aksjer bare skje for utenlandske investorer, men det er ikke gitt lovregler om rettsvern mv. for slike transaksjoner. Lovreglene om prioritet mv. gjelder bare "direkteregistrerte" aksjer. Prioritetskonflikter mellom to investorer som er registrert i den samme forvalters interne register er dermed ikke lovregulert. Det samme gjelder konflikter mellom investor og konkursboet til en forvalter som har gått konkurs. Slike konflikter må løses etter ulovfestede regler om separatistrett. I Norge vil det om kort tid oppnevnes et lovutvalg, som bl.a. vil se på denne type problemstillinger. I denne sammenheng kan nevnes at i Finland har en rekke spørsmål knyttet til forvalterregistrering blitt diskutert i en promemoria av det finske finansministeriet av 23. desember 2002. I Sverige har de funnet sin løsning i en promemoria av det svenske finansdepartementet av 20. november 2003 . 
Barriere nr. 14:

\section{Ulike regler for behandling av bilateral netting av finansielle transaksjoner}

I Giovannini-rapporten vises til at bilateral netting i mange land er begrenset til enkelte produkter eller til oppgjør gjennom enkelte systemer. Det antas imidlertid at rettslig usikkerhet som oppstår som følge av dette vil reduseres gjennom collateral-direktivet. Dette gjelder imidlertid kun i forholdt til transaksjoner som er tilknyttet finansiell sikkerhetsstillelse.

Samtlige nordiske land har gjennomført eller er i ferd med å gjennomføre direktivet, som gir klarere regler for bilateral netting på sitt område.

\section{Barriere nr. 15:}

Ulike nasjonale lovvalgsregler

I Giovannini-rapporten vises til de store problemer som kan oppstå der to ulike land har to ulike måter å løse lovvalgsproblemer på. Det vises til at det nylig vedtatte collateraldirektivet og Haag-konvensjonen vil bidra til større harmonisering på dette området. Collateraldirektivets lovvalgsregel vil sannsynligvis harmoniseres med Haagkonvensjonens regler.

Samtlige nordiske land tar sikte på å gjennomføre collateral-direktivet, og tar også sikte på å signere og ratifisere Haag-konvensjonen.

\subsection{Konklusjoner}

Det foreligger enkelte tekniske hindringer (barriere nr. 1-10), men dette er forhold som generelt bør reguleres av markedsutviklingen og markedsaktørene. Myndighetene bør være tilbakeholdne med å påtvinge aktørene bestemte tekniske løsninger. Samtidig bør myndighetene være forsiktige med å gi lovregler som i praksis påtvinger særskilte tekniske løsninger som kan vanskeliggjøre effektiv clearing- og oppgjør mellom nordiske land. Det er ikke identifisert særskilte lovregler som forhindrer en hensiktsmessig teknisk utvikling på dette området.

Videre foreligger få skattemessige hindre av den type som særskilt nevnes i Giovanninirapporten (barriere nr. 11 og 12). Det synes imidlertid som om Danmark har et etableringskrav knyttet til administrasjon av tilbakeholdskatt som etter omstendighetene kan utgjøre en barriere som nevnt i Giovannini-rapporten (barriere nr. 11). For øvrig kan det legges til grunn at ulike skatteregler mellom nordiske land i seg selv kan utgjøre en barriere for effektiv clearing og oppgjør over landegrensene, men dette er forhold som faller utenfor denne fremstillingen.

Når det gjelder rettslig usikkerhet (barriere nr. 13-15), er det generelt stor grad av samsvar mellom de nordiske lands mer grunnleggende regulering av eiendomsrett og rettigheter til verdipapirer. De ulikheter i nasjonal lovgivning som diskuteres i Giovanninirapporten, vil uansett reduseres som følge av gjennomføringen av collateral-direktivet og Haag-konvensjonen i nasjonal rett. Det kan imidlertid oppstå noe rettslig usikkerhet for utenlandske investorer som er forvalterregistrert i et norsk register, siden det ikke er gitt lovregler som regulerer deres prioritet i forhold til andre investorer (registrert hos samme forvalter) eller forvalters konkursbo. Dette er som nevnt et forhold som skal vurderes nærmere av et lovutvalg som skal nedsettes i Norge om kort tid. 
Avslutningsvis nevnes at relativt få "Giovannini-barrierer" av rettslig karakter, ikke nødvendigvis innebærer at det er et effektivt system for grensekryssende clearing og oppgjør i Norden. Det relativt lave antallet fjernmedlemmer i de ulike nordiske clearing- og oppgjørssystemer og det forholdsvis lave antallet direkte lenker mellom nordiske systemer tyder tvert i mot på at det faktisk foreligger hindre (dog av en annen art) på dette området. Slike andre hindre (dvs. hindre som ikke nevnes i Giovanninirapporten) faller utenfor denne fremstillingen, men en kan trolig legge til grunn at ulike tekniske løsninger og ulike skatteregler er to viktige grunner til den relativt lave grensekryssende aktiviteten. 